\title{
Efficacy and safety of peroral endoscopic myotomy in the management of recurrent achalasia after failed Heller myotomy: a systematic review and meta-analysis
}

\author{
Faisal Kamala, Mohammad K. Ismaila, Muhammad A. Khan ${ }^{b}$, Wade Lee-Smith', Reem Z. Sharaihad, \\ Sachit Sharma ${ }^{e}$, Stephanie McDonough ${ }^{f}$, Raseen Tariq ${ }^{g}$, Hemnishil K. Marella ${ }^{\text {, }}$ Zubair Khani, \\ Rajiv P Heda', Claudio Tombazzia ${ }^{a}$, Colin W. Howden ${ }^{a}$, Douglas G. Adler ${ }^{f}$
}

University of Tennessee Health Science Center, Memphis, NT; University of Alabama at Birmingham, AL; University of Toledo, OH; Weill Cornell Medical College, NY; University of Utah, Salt Lake City, UT; Rochester General Hospital, NY; University of Texas-Houston, Houston, TX, USA

\section{Abstract}

\begin{abstract}
Background Heller myotomy (HM) is an established treatment for achalasia but can fail in up to $10-20 \%$ of patients. Peroral endoscopic myotomy (POEM) may be an appropriate treatment for patients with failed HM.
\end{abstract}

Methods We searched several databases to identify non-comparative studies evaluating the efficacy and/or safety of POEM after failed HM and comparative studies comparing the efficacy and/or safety of POEM in patients with and without prior HM. Outcomes assessed included clinical success, technical success, adverse events, post-treatment gastroesophageal reflux disease (GERD), and presence of esophagitis on endoscopy. We calculated weighted pooled rates with $95 \%$ confidence intervals (CI) for all outcomes in patients undergoing POEM with prior HM. We calculated pooled odds ratios with $95 \% \mathrm{CI}$ to compare the outcomes between patients with and without previous HM who underwent POEM.

Results We included 11 observational studies with 1205 patients. Weighted pooled rates (95\%CI) for overall clinical success and technical success in patients with failed HM were 87\% (81-91\%) and 97\% (94-99\%), respectively. Weighted pooled rates (95\%CI) for major adverse events, new-onset GERD and presence of esophagitis on endoscopy were 5\% (2-10\%), 33\% (26$41 \%)$, and $38 \%(22-58 \%)$, respectively. There were no differences in clinical success, adverse events, post-treatment GERD and esophagitis between patients with and without previous HM.

Conclusions POEM is safe and effective in patients with failed HM and should be considered in patients with recurrent achalasia after HM. Outcomes of POEM are comparable in patients with and without prior HM.

Keywords Heller myotomy, efficacy, peroral endoscopic myotomy, meta-analysis

Ann Gastroenterol 2021; 34 (1): 1-10

\section{Introduction}

Heller myotomy (HM) and pneumatic dilation (PD) are commonly used treatment modalities for achalasia. Although

Conflict of Interest: None

Correspondence to: Douglas G. Adler MD, FACG, AGAF, FASGE, Professor of Medicine, Director, GI Fellowship Program,

Gastroenterology and Hepatology, University of Utah School of Medicine, Huntsman Cancer Center, 30N 1900E 4R118, Salt Lake City,

Utah 84132, USA, e-mail: Douglas.adler@hsc.utah.edu

Received 23 July 2020; accepted 27 August 2020;

published online 7 December 2020

DOI: https://doi.org/10.20524/aog.2020.0563
PD can achieve immediate relief of symptoms, relapse rates can approach $18 \%$ by 2 years and $41 \%$ by 5 years [1]. HM, generally accompanied by some form of fundoplication, is appropriate for patients who are good candidates for surgery. HM can achieve symptom relief in up to $90 \%$ of patients [2], with 10 year remission rates of up to $80 \%$ [3]. Possible reasons for persistent or recurrent symptoms after HM include incomplete myotomy, surgical site fibrosis, fundoplication disruption, and an excessively tight fundoplication [5]. Management of patients with failed HM is challenging, as treatment options are limited; PD and repeat HM have both been evaluated [6,7]. Although PD is associated with good long-term outcomes in patients with failed HM, repeat dilations may still be required as the relapse rate is substantial $[7,8]$. Repeat HM is associated 
${ }^{\mathrm{a} D i v i s i o n}$ of Gastroenterology, University of Tennessee Health Science Center, Memphis, TN (Faisal Kamal, Mohammad K. Ismail, Claudio Tombazzi, Colin W. Howden); ${ }^{b}$ Division of Gastroenterology, University of Alabama at Birmingham, Birmingham, AL (Muhammad A. Khan); 'Mulford Medical Sciences Library, University of Toledo, Toledo, $\mathrm{OH}$ (Wade Lee-Smith); ${ }^{\mathrm{d} D i v i s i o n}$ of Gastroenterology, Weill Cornell Medical College, NY (Reem Z. Sharaiha); ${ }^{e}$ Department of Medicine, University of Toledo, Toledo, OH (Sachit Sharma); ${ }^{\mathrm{f} D i v i s i o n}$ of Gastroenterology, University of Utah, Salt Lake City, UT (Stephanie McDonough, Douglas G. Adler); ${ }^{\mathrm{B} D e p a r t m e n t}$ of Medicine, Rochester General Hospital, Rochester, NY (Raseen Tariq); ${ }^{\text {h}}$ Department of Medicine, University of Tennessee Health Science Center, Memphis, TN (Hemnishil K. Marella); iDivision of Gastroenterology, University of Texas-Houston, Houston, TX (Zubair Khan); 'Department of Medicine, University of Tennessee Health Science Center, Memphis, TN (Rajiv P Heda), USA

with a better remission rate than PD for recurrent achalasia after HM [5].

Since its introduction in 2009, peroral endoscopic myotomy (POEM) has gained popularity in the treatment of achalasia and is used in some centers as a first-line treatment of achalasia. Compared to HM, POEM has the advantages of rapid recovery and avoiding abdominal incisions. One metaanalysis found that POEM was more effective than HM in relieving dysphagia in patients with achalasia [9]. Studies have evaluated the role of POEM in the management of recurrent achalasia after failed HM and some studies compared the outcomes of POEM in patients with and without prior HM. In this systematic review and meta-analysis, we evaluated the efficacy and safety of POEM for the treatment of recurrent achalasia after failed HM.

\section{Materials and methods}

\section{Data sources and search strategy}

We followed the guidelines for Preferred Reporting Items for Systematic Review and Meta-Analysis (PRISMA) [10] and Meta-analysis Of Observational Studies in Epidemiology (MOOSE) [11]. We conducted a comprehensive search of several databases, including PubMed \& MEDLINE, Embase, Web of Science Core Collection and the Cochrane Central Register of Controlled Trials, from inception to January 29, 2020. An experienced medical librarian (WL-S) performed the search. No language limitation was applied. The search included keywords and database-specific controlled subject terms for the concepts: peroral endoscopic myotomy, Heller's myotomy, and retreatment/prior treatment failure. Two authors (FK and SS) conducted an initial screening by independently reviewing the titles and abstracts of the articles retrieved by the search and excluded those that did not address our question of interest. Full texts of remaining articles, including references, were reviewed. The search strategy is illustrated in Fig. 1.

\section{Inclusion and exclusion criteria}

Two authors (FK and MAK) independently reviewed original studies based on inclusion criteria established a priori. We included single-arm non-comparative studies that evaluated the efficacy and/or safety of POEM in patients with prior failed HM. We also included comparative studies that compared the efficacy and/or safety of POEM in patients with and without prior HM. Case reports, case series with fewer than 5 patients, guidelines, editorials, review articles and studies with animal models were excluded. We only included full publications as well as abstracts. All articles were downloaded into Endnote X9.0, a bibliographic database manager. Duplicate citations were removed.

\section{Data extraction}

Two authors (FK and MAK) independently assessed the eligibility of included studies and designed data extraction forms for this study. They then collected data independently using these forms and discussed any discrepancies with a third reviewer (MKI); agreement was reached by consensus. Data extracted included year and country of publication, type of study, patient demographics, number of patients, technical success, clinical success, major adverse events, pre-and post-treatment Eckardt score [13], operative time, length of stay, duration of follow up, post-treatment new onset gastroesophageal reflux disease (GERD) based on patients' reporting of symptoms, presence of esophagitis on esophagogastroduodenoscopy (EGD), and GERD confirmed by $24-\mathrm{h} \mathrm{pH}$ monitoring.

\section{Quality assessment}

We assessed the quality of comparative studies using the Newcastle-Ottawa Scale (NOS). The NOS assesses the quality of observational studies based on selection, comparability and exposure/outcome, and allocates a maximum of 4,2 , and 3 points, respectively. Studies that score more than 7 are considered high quality, those that score between 5 and 7 are considered moderate quality, and those that score below 5 are considered low quality. We performed quality assessment of non-comparative studies using a modified version of the NOS, which allocates a maximum of 6 points [14]. On this modified score, high quality studies score over 3 while low quality studies score 3 or below. Two authors (ZK and RT) independently performed the quality assessment and any disagreement was discussed with a third reviewer $(\mathrm{CWH})$.

\section{Data synthesis and statistical analysis}

The primary outcome of interest for POEM with prior failed HM was clinical success, defined as a post-treatment Eckardt score of $\leq 3$. Secondary outcomes of interest were technical success (defined as successful completion of the procedure), procedure time, major adverse events, post- 


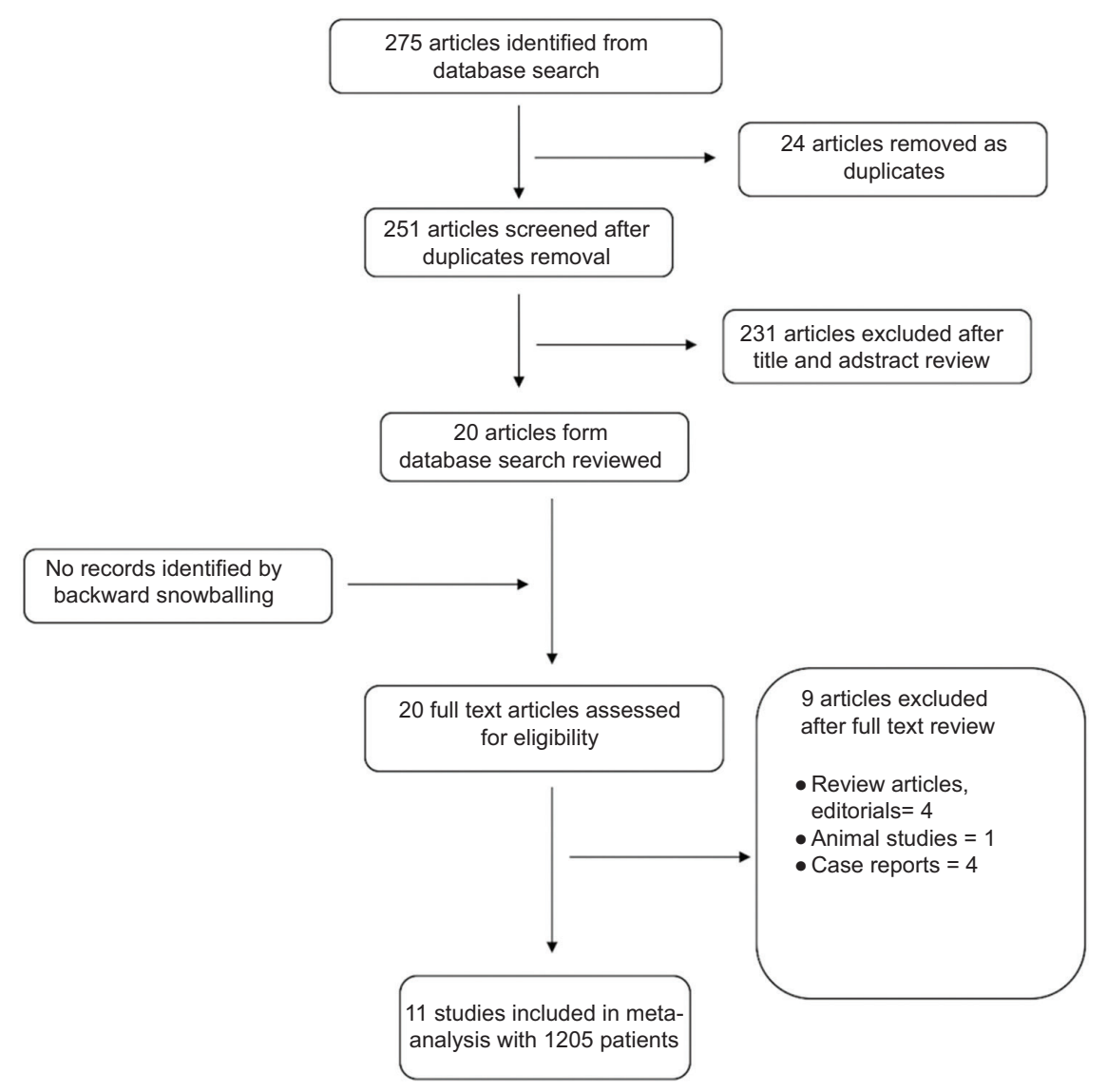

Figure 1 PRISMA flowchart

treatment new onset symptomatic GERD (based on patients' reporting of symptoms) and presence of esophagitis on EGD. The major adverse events that we included in our analysis were those that required intervention or were determined to be moderate or severe according to the American Society for Gastrointestinal Endoscopy (ASGE) lexicon system [4] or as described in the Natural Orifice Surgery Consortium for Assessment and Research (NOSCAR) white paper [15]. For single arm, non-comparative studies, we calculated weighted pooled rates with $95 \%$ confidence intervals (CI) for technical and clinical success, major adverse events and rate of postprocedure new onset symptomatic GERD. For comparative studies, we calculated pooled odds ratios (OR) with 95\%CI to compare clinical success, risk of new onset symptomatic GRED, esophagitis on endoscopy, and adverse events between groups with and without prior HM. We calculated standard mean difference (SMD) with $95 \%$ CI to compare operative times between groups. Some studies reported operative times as mean \pm standard deviation (SD) and others as median and interquartile range (IQR). According to the Cochrane handbook, "when sample sizes are large and the distribution of the outcome is similar to the normal distribution, the width of the interquartile range will be approximately 1.35 standard deviations" [26]. We used this approach to calculate SMD.

We used a fixed effect model for most of our analyses. However, we used a random effects model when significant heterogeneity was encountered in data, as recommended by the Cochrane handbook. Heterogeneity was assessed by the $I^{2}$ statistic. The statistical analysis was performed using Review Manager (RevMan, version 5.3 for Windows; The Cochrane Collaboration, The Nordic Cochrane Centre, Copenhagen, Denmark, 2014) and comprehensive meta-analysis (CMA) software.

\section{Results}

\section{Search strategy yield and quality assessment}

The search strategy yielded 275 articles (Fig. 1), from which we removed 24 duplicates. Of the remaining 251 articles, 231 were removed after title and abstract review. No relevant articles were identified from a search of bibliographies in the retrieved publications. We reviewed the full texts of 20 articles, from which we ultimately included 11 studies comprising 1205 patients [4,16-25]. Eight were full publications [4,16-22] and 3 were abstracts [23-25]. Of these, 6 [18-23] (110 patients) were noncomparative and comprised only patients with prior failed HM. The other $5[4,16,17,24,25]$ were comparative studies comprising 193 patients with, and 902 without, prior HM. The characteristics of the included studies are summarized in Tables 1 and 2. The quality assessment of studies is summarized in Table 1. 
Table 1 Characteristics of studies

\begin{tabular}{|c|c|c|c|c|c|c|c|}
\hline Study, year & Country & Type of study & $\begin{array}{l}\text { Total number } \\
\text { of patients }\end{array}$ & Males & Inclusion criteria & Exclusion criteria & $\begin{array}{c}\text { Quality assessment } \\
\text { NOS score }\end{array}$ \\
\hline $\begin{array}{l}\text { Zhang et al, } \\
2018[16]\end{array}$ & USA & Prospective & 318 & 179 & $\begin{array}{l}\text { Patients undergoing } \\
\text { POEM at Winthrop } \\
\text { University } \\
\text { Hospital. Patients } \\
\text { with prior HM were } \\
\text { identified and analyzed } \\
\text { as a subgroup. }\end{array}$ & $\begin{array}{l}\text { Patients with } \\
\text { uncorrectable } \\
\text { coagulopathy and severe } \\
\text { lung disease requiring } \\
\text { oxygen supplementation } \\
\text { as well as steroid- } \\
\text { dependent patients and } \\
\text { patients with expected } \\
\text { survival }<12 \text { months }\end{array}$ & 7 \\
\hline $\begin{array}{l}\text { Ngamruengphong } \\
\text { et al,, 2017 [4] }\end{array}$ & Multicenter & Retrospective & 180 & 82 & $\begin{array}{l}\text { Adult patients (age } \\
\geq 18 \text { years) with } \\
\text { achalasia and Eckardt } \\
\text { scores of } 3 \text { or higher } \\
\text { who underwent } \\
\text { POEM }\end{array}$ & $\begin{array}{l}\text { Patients with a history } \\
\text { of prior POEM, patients } \\
\text { with esophageal cancer, } \\
\text { and patients with a } \\
\text { history of esophageal } \\
\text { surgery (other than HM). }\end{array}$ & 7 \\
\hline $\begin{array}{l}\text { Kristensen et al, } \\
2017 \text { [17] }\end{array}$ & Denmark & Prospective & 66 & 33 & $\begin{array}{l}\text { Patients who } \\
\text { underwent POEM for } \\
\text { achalasia }\end{array}$ & $\begin{array}{l}\text { Patients who did } \\
\text { not fulfill the initial } \\
\text { 3-month follow up, } \\
\text { patients in whom the } \\
\text { procedure could not be } \\
\text { completed for technical } \\
\text { reasons, re-POEMs } \\
\text { and patients with } \\
\text { Jackhammer esophagus }\end{array}$ & 6 \\
\hline $\begin{array}{l}\text { Tyberg } \\
\text { et al, } 2017 \text { [18] }\end{array}$ & Multicenter & Prospective & 51 & 24 & $\begin{array}{l}\text { Patients who } \\
\text { underwent POEM } \\
\text { post-HM from } 13 \\
\text { centers in } 9 \text { countries } \\
\text { were included }\end{array}$ & NR & 5 \\
\hline $\begin{array}{l}\text { Fumagalli } \\
\text { et al, } 2015 \text { [19] }\end{array}$ & Italy & Retrospective & 6 & 3 & $\begin{array}{l}\text { Patients who had } \\
\text { previously undergone } \\
\text { myotomy for achalasia } \\
\text { and subsequently } \\
\text { underwent a repeated } \\
\text { myotomy for persistent } \\
\text { or recurrent dysphagia }\end{array}$ & $\begin{array}{l}\text { Esophageal varices, } \\
\text { coagulopathy, } \\
\text { active esophagitis, } \\
\text { gastroesophageal } \\
\text { malignancy }\end{array}$ & \\
\hline $\begin{array}{l}\text { Vigneswaran } \\
\text { et al, } 2014 \text { [20] }\end{array}$ & USA & Prospective & 5 & 4 & $\begin{array}{l}\text { Patients with recurrent } \\
\text { dysphagia symptoms } \\
\text { after failed Heller } \\
\text { myotomy for achalasia }\end{array}$ & $\begin{array}{l}\text { Esophageal varices, } \\
\text { coagulopathy, active } \\
\text { esophagitis, pregnancy, } \\
\text { known gastroesophageal } \\
\text { malignancy, age less } \\
\text { than } 18 \text { years }\end{array}$ & 2 \\
\hline $\begin{array}{l}\text { Onimaru et al, } \\
2013 \text { [21] }\end{array}$ & Japan & Prospective & 10 & 5 & $\begin{array}{l}\text { Patients with persistent } \\
\text { or recurrent achalasia } \\
\text { who previously } \\
\text { underwent surgical } \\
\text { myotomy as a first-line } \\
\text { treatment. All failed } \\
\text { surgical myotomy } \\
\text { patients received } \\
\text { PBD as the first line } \\
\text { rescue treatment, and } \\
\text { in patients with no } \\
\text { symptomatic relief } \\
\text { after PBD, POEM was } \\
\text { considered as a second } \\
\text { line rescue treatment }\end{array}$ & NR & 3 \\
\hline
\end{tabular}


Table 1 (Continued)

\begin{tabular}{|c|c|c|c|c|c|c|c|}
\hline Study, year & Country & Type of study & $\begin{array}{c}\text { Total number } \\
\text { of patients }\end{array}$ & Males & Inclusion criteria & Exclusion criteria & $\begin{array}{c}\text { Quality assessment } \\
\text { NOS score }\end{array}$ \\
\hline $\begin{array}{l}\text { Zhou et al, } \\
2012[22]\end{array}$ & China & Prospective & 12 & 5 & $\begin{array}{l}\text { Patients } \geq 18 \text { years } \\
\text { who had recurrence/ } \\
\text { persistence of } \\
\text { symptoms after } \\
\text { primary Heller } \\
\text { myotomy, with an } \\
\text { Eckardt symptom } \\
\text { score of } \geq 4\end{array}$ & $\begin{array}{l}\text { severe cardiopulmonary } \\
\text { disease or other serious } \\
\text { disease leading to } \\
\text { unacceptable surgical } \\
\text { risk, pseudoachalasia, } \\
\text { and megaesophagus } \\
\text { (diameter }>7 \mathrm{~cm} \text { ) }\end{array}$ & 4 \\
\hline $\begin{array}{l}\text { Parikh et al, } \\
2018 \text { [25] }\end{array}$ & USA & Prospective & 138 & NR & $\begin{array}{l}\text { Achalasia patients who } \\
\text { underwent POEM with } \\
\text { at least } 2 \text { months post } \\
\text { treatment follow up }\end{array}$ & NR & \\
\hline $\begin{array}{l}\text { Chavan et al, } \\
2017 \\
\text { Abstract [23] }\end{array}$ & India & Retrospective & 26 & NR & $\begin{array}{l}\text { All patients who } \\
\text { underwent POEM with } \\
\text { history of failed HM }\end{array}$ & NR & \\
\hline $\begin{array}{l}\text { Landi et al, } \\
2017 \text { [24] }\end{array}$ & Italy & Prospective & 393 & NR & $\begin{array}{l}\text { Patients who underwent } \\
\text { POEM because of } \\
\text { recurrent symptoms } \\
\text { after a failed HM }\end{array}$ & NR & \\
\hline
\end{tabular}

POEM, peroral endoscopic myotomy; HM, Heller myotomy; NR, not reported; PBD, pneumatic balloon dilation

\section{Meta-analysis}

\section{Clinical success}

9 studies with 1001 patients $[4,16,18-24]$ reported data on this outcome. Weighted pooled rates $(95 \% \mathrm{CI})$ were $87 \%$ (81-91\%), Cochran $\mathrm{Q}$ test $\mathrm{P}=0.17, I^{2}=31 \%$ (Fig. 2A). Three studies $[4,16,24]$ with 882 patients compared clinical success in patients with and without prior HM. We found no difference in clinical success between the 2 groups; pooled OR (95\%CI) 2.30 (0.83-6.43), Cochran Q test $\mathrm{P}=0.15, I^{2}=47 \%$ (Fig. 2B).

\section{Technical success}

Nine studies with 1001 patients $[4,16,18-24]$ reported data on this outcome. Weighted pooled rates $(95 \% \mathrm{CI})$ were $97 \%$ (94-99\%), Cochran Q test $\mathrm{P}=0.96, I^{2}=0 \%$ (Fig. 3).

\section{Major adverse events}

We included 7 studies with 582 patients [4,16,18-22]. Weighted pooled rates $(95 \% \mathrm{CI})$ were $5 \%(2-10 \%), \mathrm{P}=0.26$, $I^{2}=22 \%$ (Fig. 4). In 2 studies [4,16] with 498 patients that compared adverse events in patients with and without prior $\mathrm{HM}$, we found no difference between the 2 groups: pooled OR (95\%CI) 0.52 (0.12-2.33), Cochran Q test $\mathrm{P}=0.68, I^{2}=0 \%$.

\section{Post-treatment GERD and esophagitis}

We included 5 studies with 969 patients [4,16,17,22,24]. Weighted pooled rates for new onset symptomatic GERD (based on patients' reporting of symptoms) were 33\% (26-41\%), $I^{2}=37 \%$ (Supplementary Fig. 1). Three studies [4,16,22] evaluated the presence of esophagitis on EGD after POEM: weighted pooled rates were $38 \%$ (22-58\%), $I^{2}=52 \%$ (Supplementary Fig. 2).

Four studies $[4,16,17,24]$ compared the rates of GERD between patients with and without prior HM and found no significant difference between the 2 groups; pooled OR (95\%CI) 1.28 (0.83-1.96) Cochran $\mathrm{Q}$ test $\mathrm{P}=0.38, I^{2}=2 \%$ (Supplementary Fig. 3A). Two studies $[4,16]$ compared rates of esophagitis (confirmed by EGD) between patients with and without prior HM and found no significant difference between the 2 groups, pooled OR (95\%CI) 1.09 (0.60-1.98), Cochran $\mathrm{Q}$ test $\mathrm{P}=0.17, I^{2}=47 \%$ (Supplementary Fig. $3 \mathrm{~B}$ ). Overall, there was no significant difference in the rates of symptomatic GERD and esophagitis between patients with and without prior HM.

Only one study reported data on GERD confirmed by 24-h $\mathrm{pH}$ monitoring: rates of GERD in patients with and without prior $\mathrm{HM}$ were $50 \%$ and $48 \%$ respectively.

\section{Operative time}

Five studies [4,16,17,24,25] compared operative time between patients with and without prior HM. We found that operative time was longer in patients with prior HM: SMD (95\%CI) $0.212(0.03-0.39), I^{2}=0 \%$.

\section{Discussion}

We found that POEM is a safe and effective option for patients with recurrent achalasia after HM and that outcomes of 


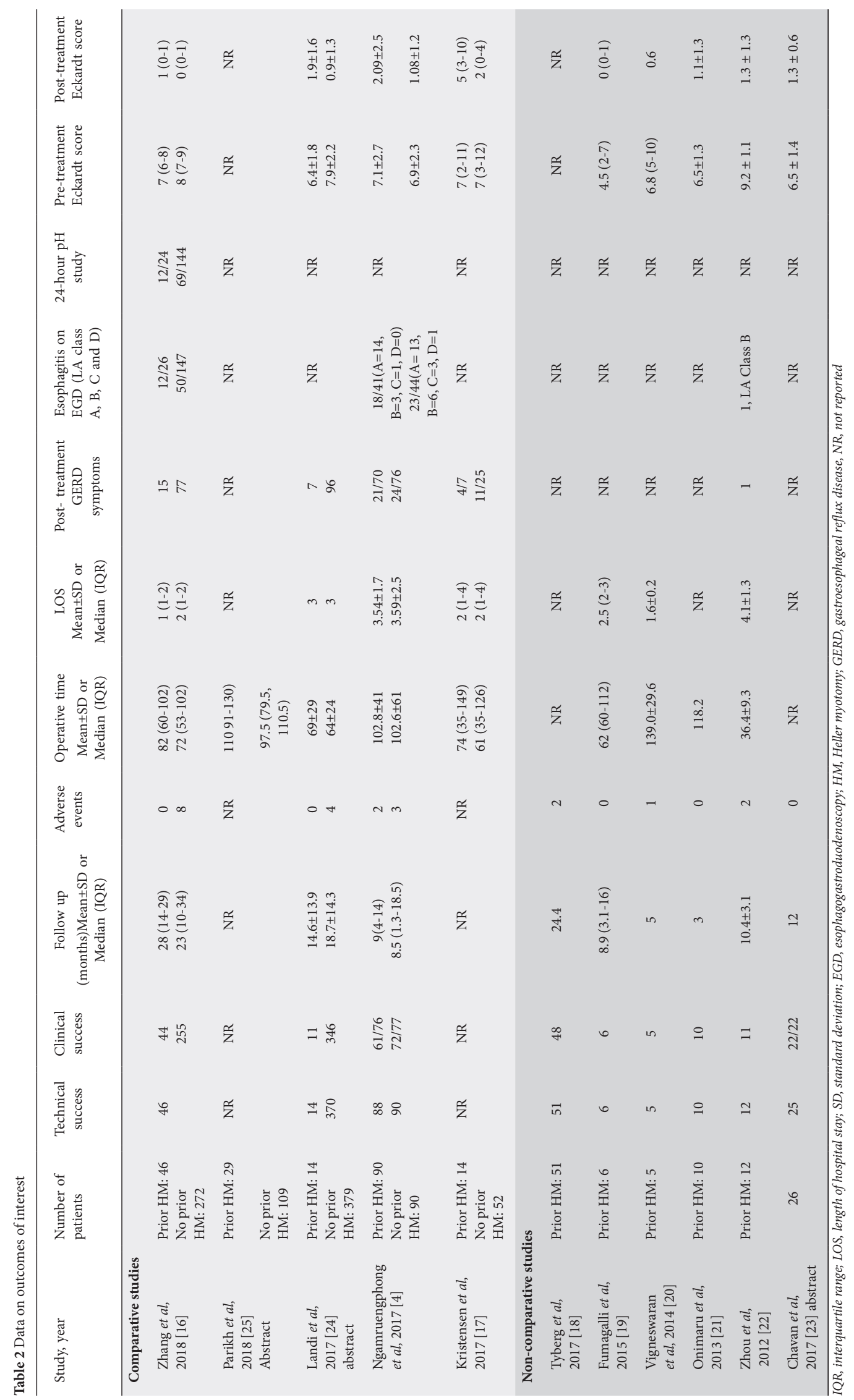


POEM in these patients are comparable to those without prior HM. Traditionally, PD and repeat HM have been mainstays of treatment in patients with failed HM. Kumbhari et al reported that the rate of remission in patients receiving PD (with repeat dilations as required) after failed $\mathrm{HM}$ at a median follow up of 30 months was 95\% [8]. However, the need for repeat dilations, with the consequent increased risk of adverse events, most notably perforation, limits the usefulness of PD in this patient population. Repeat HM is often performed in these patients, but can be technically challenging because of adhesions from previous surgery [22], and also carries a risk of serious adverse events [27].

We found that the overall technical success rate for POEM after failed HM was 97\% (94-99\%) comparable to the reported rate of $98 \%$ in patients without prior HM [28]. The overall clinical success rate for POEM after failed HM was 87\% (81$91 \%$ ), equivalent to the figure of $86.9 \%$ for repeat HM. Wang et al reported that the rate of recurrent achalasia with repeat HM after failed HM was $86.9 \%$ [5]. The clinical success rate of POEM after failed HM appears comparable to that of POEM without prior HM. We also found that the clinical success rate for POEM was comparable between patients with and without prior HM, pooled OR (95\%CI) 2.30 (0.83-6.43). However, this analysis had only moderate heterogeneity $\left(I^{2}=47 \%\right)$, which limits the validity of its results.

The overall rate of major adverse events was $5 \%$ and there were no cases of esophageal perforation. A previous systematic review of 7 studies evaluating the feasibility and safety of laparoscopic repeat HM reported intraoperative esophageal or gastric perforation in $16 \%$ of patients, with $4 \%$ requiring conversion to an open procedure [27]. HM is also more invasive and is associated with longer procedure and recovery times than POEM.

The analysis of procedure time was limited, as some studies reported this as mean $\pm \mathrm{SD}$ and others as median (IQR). However, procedure time was typically longer in patients with prior HM compared to those without, probably because of fibrosis and adhesions from prior surgery. Contrary to other studies, Ngamruengphong et al [4] reported that procedure time was the same in both groups. However, they included a higher proportion of patients in the prior HM group who had undergone previous attempts at $\mathrm{PD}$, compared to patients without prior $\mathrm{HM}$ ( $44 \%$ vs. $25 \%$ ), which may explain this discrepancy.

One of the strengths of our work is the inclusion of both single-arm and comparative studies to estimate the overall efficacy and safety of POEM after failed HM, as well as comparative efficacy and safety compared to patients without prior HM. Analyses of most of the outcomes that we assessed had low heterogeneity.

This meta-analysis also has some limitations. To date, no randomized controlled trial has compared POEM in patients with and without prior HM. Consequently, our meta-analysis only included observational studies, which entail risks of measured and unmeasured confounding [29]. In many of the included studies, patients received other treatments, including botulinum toxin injections and PD that could have affected the performance of POEM. In a study by Onimaru et al, all patients underwent PD as first-line rescue treatment after failed HM, and patients with no response to PD underwent POEM. The analysis of our primary outcome of interest (clinical success) was limited by moderate heterogeneity. Follow-up periods varied across different studies, which may have led to clinical heterogeneity in the analysis. Only few comparative studies reported data on all of the outcomes we assessed and the data may not be sufficiently powered to draw firm conclusions. Finally, most of the included studies did not report the efficacy and safety of POEM in individual achalasia subtypes.

In conclusion, this systematic review and meta-analysis supports the role of POEM in patients with no improvement in achalasia symptoms or recurrence of symptoms after HM.

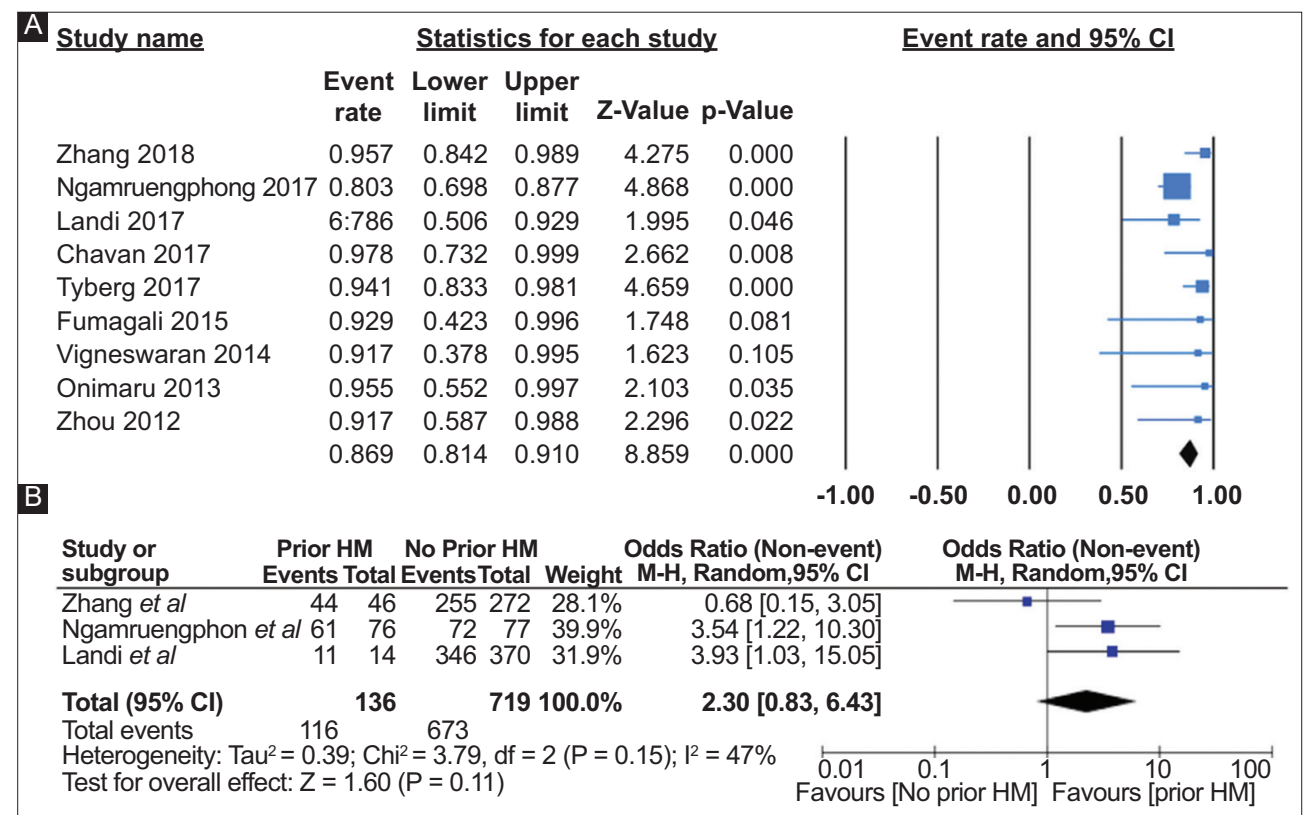

Figure 2 Clinical success of peroral endoscopic myotomy (POEM) after failed Heller myotomy (HM) (overall and comparative). (A) Overall clinical success of POEM after failed HM. (B) Comparison of clinical success of POEM in patients with and without prior HM 


\begin{tabular}{|c|c|c|c|c|c|c|c|c|c|c|}
\hline \multirow[t]{2}{*}{ Study name } & \multicolumn{5}{|c|}{ Statistics for each study } & \multicolumn{5}{|c|}{ Event rate and $95 \% \mathrm{Cl}$} \\
\hline & $\begin{array}{c}\text { Event } \\
\text { rate }\end{array}$ & $\begin{array}{c}\text { Lower } \\
\text { limit }\end{array}$ & $\begin{array}{l}\text { Upper } \\
\text { limit }\end{array}$ & Z-Value & p-Value & & & & & \\
\hline Zhang 2018 & 0.989 & 0.851 & 0.999 & 3.188 & 0.001 & & & & & $\rightarrow$ \\
\hline Nganrruengphong 2017 & 0.978 & 0.915 & 0.994 & 5.292 & 0.000 & & & & & \\
\hline Landi 2017 & 0.967 & 0.634 & 0.998 & 2.341 & 0.019 & & & & & $\Rightarrow$ \\
\hline Chavan 2017 & 0.962 & 0.772 & 0.995 & 3.156 & 0.002 & & & & & - \\
\hline Tyberg 2017 & 0.990 & 0.864 & 0.999 & 3.261 & 0.001 & & & & & $\rightarrow$ \\
\hline Fumagali 2015 & 0.929 & 0.423 & 0.996 & 1.748 & 0.081 & & & & & $=$ \\
\hline Vigneswaran 2014 & 0.917 & 0.378 & 0.995 & 1.623 & 0.105 & & & & & $\rightarrow$ \\
\hline Onimaru et al & 0.955 & 0.552 & 0.997 & 2.103 & 0.035 & & & & & $\rightarrow$ \\
\hline \multirow[t]{3}{*}{ Zhou 2012} & 0.962 & 0.597 & 0.998 & 2.232 & 0.026 & & & & & -2 \\
\hline & 0.971 & 0.938 & 0.986 & 8.766 & 0.000 & & & & & 1 \\
\hline & & & & & & -1.00 & -0.50 & 0.00 & 0.50 & 1.00 \\
\hline
\end{tabular}

Figure 3 Overall technical success of peroral endoscopic myotomy after failed Heller myotomy

\begin{tabular}{|c|c|c|c|c|c|c|c|c|c|c|}
\hline \multirow[t]{2}{*}{ Study name } & \multicolumn{5}{|c|}{ Statistics for each study } & & \multicolumn{4}{|c|}{ Event rate and $95 \% \mathrm{Cl}$} \\
\hline & $\begin{array}{l}\text { Event } \\
\text { rate }\end{array}$ & $\begin{array}{l}\text { Lower } \\
\text { limit }\end{array}$ & $\begin{array}{l}\text { Upper } \\
\text { limit }\end{array}$ & Z-Value & p-Value & & & & & \\
\hline Zhang 2018 & 0.011 & 0.001 & 0.149 & -3.188 & 0.001 & & & & & \\
\hline Nganrruengphong 2017 & 0.022 & 0.006 & 0.085 & -5.292 & 0.000 & & & & & \\
\hline Tyberg 2017 & 0.039 & 0.010 & 0.144 & -4.434 & 0.000 & & & & & \\
\hline Fumagali 2015 & 0.071 & 0.004 & 0.577 & -1.748 & 0.081 & & & & & \\
\hline Vigneswaran 2014 & 0.200 & 0.027 & 0.691 & -1.240 & 0.215 & & & - & & \\
\hline Onimaru 2013 & 0.045 & 0.003 & 0.448 & -2.103 & 0.035 & & & & & \\
\hline \multirow[t]{3}{*}{ Zhou 2012} & 0.167 & 0.042 & 0.477 & -2.078 & 0.038 & & & & & \\
\hline & 0.054 & 0.028 & 0.104 & -7.968 & 0.000 & & & $\downarrow$ & & \\
\hline & & & & & & -1.00 & -0.50 & 0.00 & 0.50 & 1.00 \\
\hline
\end{tabular}

Figure 4 Adverse events with peroral endoscopic myotomy after failed Heller myotomy

\section{Summary Box}

\section{What is already known:}

- Management of patients with failed Heller myotomy (HM) is challenging and treatment options are limited

- Pneumatic dilation (PD) can be used in these patients but its usefulness is limited by a high relapse rate

- Repeat HM is associated with increased risk of complications

- Peroral endoscopic myotomy (POEM) may be a suitable option in patients with failed HM

\section{What the new findings are:}

- POEM is a safe and effective option in patients with recurrence of symptoms after prior HM

- Outcomes of POEM in patients with prior HM are comparable to outcomes in patients withoutprior HM

- POEM should be considered in patients with failed HM

\section{References}

1. Elliott TR, Wu PI, Fuentealba S, Szczesniak M, de Carle DJ, Cook IJ. Long-term outcome following pneumatic dilatation as initial therapy for idiopathic achalasia: an 18-year single-centre experience. Aliment Pharmacol Ther 2013;37:1210-1219.

2. Campos GM, Vittinghoff E, Rabl C, et al. Endoscopic and surgical treatments for achalasia: a systematic review and meta-analysis. Ann Surg 2009;249:45-57.

3. Weber CE, Davis CS, Kramer HJ, Gibbs JT, Robles L, Fisichella PM. Medium and long-term outcomes after pneumatic dilation or laparoscopic Heller myotomy for achalasia: a meta-analysis. Surg Laparosc Endosc Percutan Tech 2012;22:289-296.

4. Ngamruengphong $\mathrm{S}$, Inoue $\mathrm{H}$, Ujiki MB, et al. Efficacy and safety of peroral endoscopic myotomy for treatment of achalasia after failed Heller myotomy. Clin Gastroenterol Hepatol 2017;15:1531-1537.

5. Wang L, Li YM. Recurrent achalasia treated with Heller myotomy: a review of the literature. World J Gastroenterol 2008;14:7122-7126.

6. Mandovra P, Kalikar V, Patel A, Patankar RV. Redo laparoscopic Heller's cardiomyotomy for recurrent achalasia: is laparoscopic surgery feasible? J Laparoendosc Adv Surg Tech A 2018;28:298-301.

7. Legros L, Ropert A, Brochard C, et al. Long-term results of pneumatic dilatation for relapsing symptoms of achalasia after Heller myotomy. Neurogastroenterol Motil 2014;26:1248-1255.

8. Kumbhari V, Behary J, Szczesniak M, Zhang T, Cook IJ. Efficacy and safety of pneumatic dilatation for achalasia in the treatment of post-myotomy symptom relapse. Am J Gastroenterol 2013;108:1076-1081.

9. Schlottmann F, Luckett DJ, Fine J, Shaheen NJ, Patti MG. 
Laparoscopic Heller myotomy versus peroral endoscopic myotomy (POEM) for achalasia: a systematic review and meta-analysis. Ann Surg 2018;267:451-460.

10. Liberati A, Altman DG, Tetzlaff J, et al. The PRISMA statement for reporting systematic reviews and meta-analyses of studies that evaluate healthcare interventions: explanation and elaboration. BMJ 2009;339:b2700.

11. Stroup DF, Berlin JA, Morton SC, et al. Meta-analysis of observational studies in epidemiology: a proposal for reporting. Meta-analysis Of Observational Studies in Epidemiology (MOOSE) group. JAMA 2000;283:2008-2012.

12. Taddio A, Pain T, Fassos FF, Boon H, Ilersich AL, Einarson TR. Quality of nonstructured and structured abstracts of original research articles in the British Medical Journal, the Canadian Medical Association Journal and the Journal of the American Medical Association. CMAJ 1994;150:1611-1615.

13. Eckardt VF, Aignherr C, Bernhard G. Predictors of outcome in patients with achalasia treated by pneumatic dilation. Gastroenterology 1992;103:1732-1738.

14. Stang A. Critical evaluation of the Newcastle-Ottawa scale for the assessment of the quality of nonrandomized studies in metaanalyses. Eur J Epidemiol 2010;25:603-605.

15. Stavropoulos SN, Desilets DJ, Fuchs KH, et al; NOSCAR POEM White Paper Committee. Per-oral endoscopic myotomy white paper summary. Gastrointest Endosc 2014;80:1-15.

16. Zhang X, Modayil RJ, Friedel D, et al. Per-oral endoscopic myotomy in patients with or without prior Heller's myotomy: comparing long-term outcomes in a large U.S. single-center cohort (with videos). Gastrointest Endosc 2018;87:972-985.

17. Kristensen H, Kirkegård J, Kjær DW, Mortensen FV, Kunda R, Bjerregaard NC. Long-term outcome of peroral endoscopic myotomy for esophageal achalasia in patients with previous Heller myotomy. Surg Endosc 2017;31:2596-2601.

18. Tyberg A, Sharaiha RZ, Familiari P, et al. Peroral endoscopic myotomy as salvation technique post-Heller: international experience. Dig Endosc 2018;30:52-56.

19. Fumagalli U, Rosati R, De Pascale S, et al. Repeated surgical or endoscopic myotomy for recurrent dysphagia in patients after previous myotomy for achalasia. J Gastrointest Surg 2016;20:494-499.

20. Vigneswaran Y, Yetasook AK, Zhao JC, Denham W, Linn JG, Ujiki MB. Peroral endoscopic myotomy (POEM): feasible as reoperation following Heller myotomy. $J$ Gastrointest Surg 2014;18:1071-1076.

21. Onimaru $\mathrm{M}$, Inoue $\mathrm{H}$, Ikeda $\mathrm{H}$, et al. Peroral endoscopic myotomy is a viable option for failed surgical esophagocardiomyotomy instead of redo surgical Heller myotomy: a single center prospective study. J Am Coll Surg 2013;217:598-605.

22. Zhou PH, Li QL, Yao LQ, et al. Peroral endoscopic remyotomy for failed Heller myotomy: a prospective single-center study. Endoscopy 2013;45:161-166.

23. Chavan R, Ramchandani M, Nabi Z, et al. Per oral endoscopic myotomy for failed hellers myotomy in patients with achalasia cardia: Our experience. Dig Endosc 2017;29(Suppl):235-236.

24. Landi R, Familiari P, Calì A, et al. Per-oral endoscopic myotomy as rescue therapy in patients with symptoms recurrence after surgical myotomy. A single centre experience with mid-term follow-up. Dig Liv Dis 2017;49 Suppl 2:e86-e87.

25. Parikh MP, Thota PN, Gupta NM, et al. Comparison of outcomes of per-oral endoscopic mytomy (POEM) in achalasia patients with or without prior laparoscopic heller's myotomy (LHM). United European Gastroenterology Journal 2018;6:A33-A34.

26. Cumpston M, Li T, Page MJ, et al. Updated guidance for trusted systematic reviews: a new edition of the Cochrane Handbook for Systematic Reviews of Interventions. Cochrane Database Syst Rev 2019;10:ED000142.

27. James DR, Purkayastha S, Aziz O, et al. The feasibility, safety and outcomes of laparoscopic re-operation for achalasia. Minim Invasive Ther Allied Technol 2012;21:161-167.

28. Ofosu A, John F, Meybodi MA, et al. The efficacy and safety of peroral endoscopic myotomy versus pneumatic dilation in the treatment of 3,844 achalasia patients: a systematic review and meta-analysis. Gastrointest Endosc 2019;89 Suppl:AB83-AB84.

29. Sørensen HT, Lash TL, Rothman KJ. Beyond randomized controlled trials: a critical comparison of trials with nonrandomized studies. Hepatology 2006;44:1075-1082. 


\section{Supplementary material}

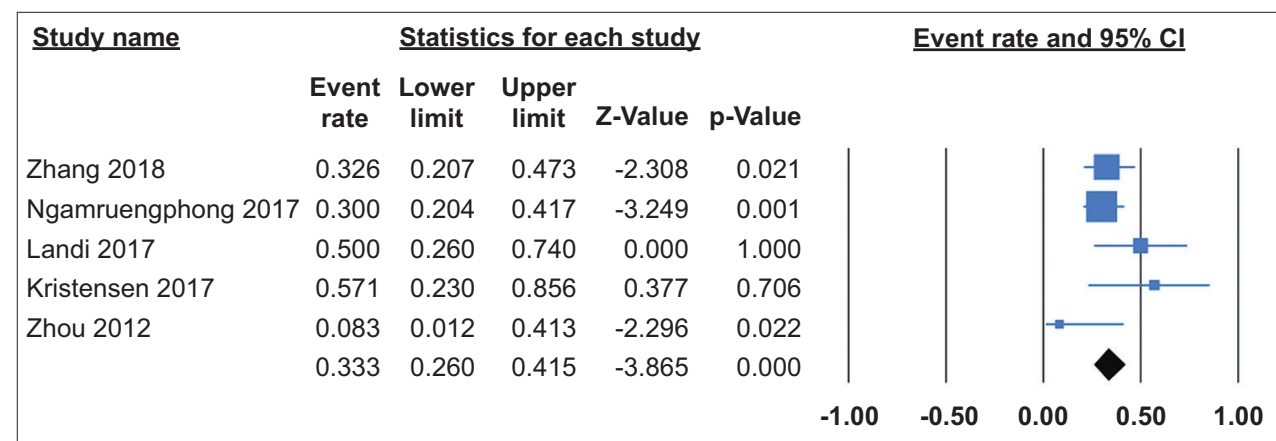

Supplementary Figure 1 Overall Risk of GERD with POEM after failed HM

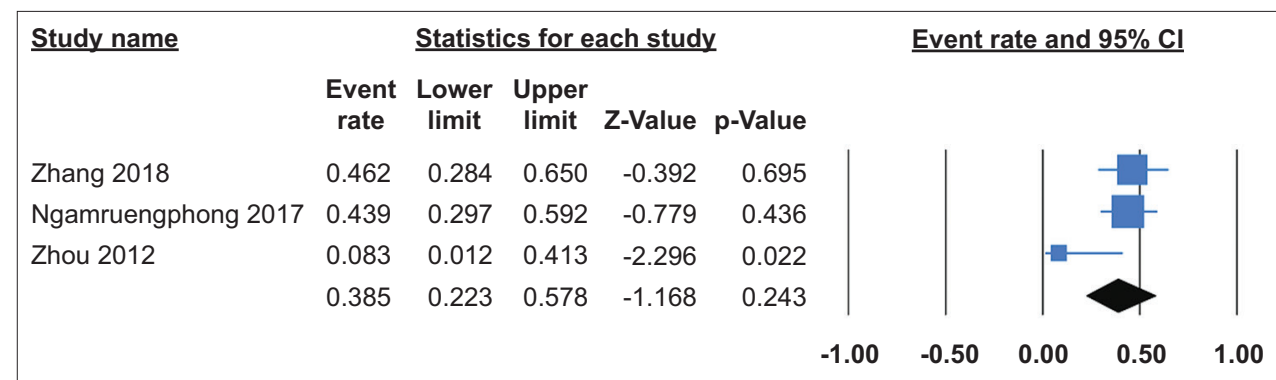

Supplementary Figure 2 Overall risk of esophagitis with POEM after failed HM

\begin{tabular}{|c|c|c|c|c|c|c|}
\hline $\begin{array}{l}\text { Study or } \\
\text { subgroup }\end{array}$ & $\begin{array}{l}\text { Prior Hn } \\
\text { Events Tc }\end{array}$ & $\begin{array}{l}\text { M } \\
\text { otal } \\
\end{array}$ & $\begin{array}{l}\text { No Prio } \\
\text { Events T }\end{array}$ & rotal Weight & $\begin{array}{l}\text { Odds Ratio } \\
\text { M-H, Fixed,95\% Cl }\end{array}$ & $\begin{array}{l}\text { Odds Ratio } \\
\text { M-H, Fixed, } 95 \% \mathrm{Cl}\end{array}$ \\
\hline Kristensen et al & 4 & 7 & 11 & $25 \quad 5.6 \%$ & $1.70[0.31,9.22]$ & \\
\hline Laridi et al & 7 & 14 & 96 & $3709.5 \%$ & $2.85[0.98,8.35]$ & \\
\hline Ngamruengphon et al & 21 & 70 & 24 & $7643.9 \%$ & $0.93[0.46,1.88]$ & \\
\hline Zhang et al & 15 & 46 & 77 & $27240.9 \%$ & $1.23[0.63,2.40]$ & \\
\hline Total $(95 \% \mathrm{Cl})$ & & 137 & & $743 \quad 100.0 \%$ & $1.28[0.83,1.96]$ & \\
\hline Total events & 47 & & 208 & & & \\
\hline $\begin{array}{l}\text { Heterogeneity: } \mathrm{Chi}^{2}=3.0 \\
\text { Test for overall effect: } Z=\end{array}$ & $\begin{array}{l}07, \mathrm{df}= \\
=1.12(\mathrm{P}\end{array}$ & $\begin{array}{l}3(P \\
P=0\end{array}$ & $\begin{array}{l}=0.38) ; \\
0.26)\end{array}$ & $I^{2}=2 \%$ & 0.01 & 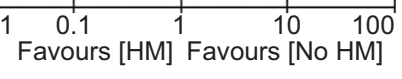 \\
\hline $\begin{array}{l}\text { Study or } \\
\text { subgroup }\end{array}$ & $\begin{array}{l}\text { Prior } \mathrm{HI} \\
\text { vents Tc }\end{array}$ & & $\begin{array}{l}\text { No Prior } \\
\text { Events T }\end{array}$ & $\begin{array}{l}\text { r HM } \\
\text { otal Weight }\end{array}$ & $\begin{array}{c}\text { Odds Ratio } \\
\text { M-H, Fixed,95\% Cl }\end{array}$ & $\begin{array}{l}\text { Odds Ratio } \\
\text { M-H, Fixed, } 95 \% \mathrm{Cl}\end{array}$ \\
\hline Ngamruengphon et al & 18 & 41 & 23 & $4460.6 \%$ & $0.71[0.30,1.68]$ & 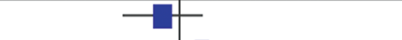 \\
\hline Zhang et al & 12 & 26 & 50 & $14739.4 \%$ & $1.66[0.72,3.86]$ & \\
\hline Total $(95 \% \mathrm{Cl})$ & & 67 & & $191100.0 \%$ & $1.09[0.60,1.98]$ & \\
\hline Total events & 30 & & 73 & & & \\
\hline \multicolumn{5}{|c|}{$\begin{array}{l}\text { Heterogeneity: } \mathrm{Chi}^{2}=1.96, \mathrm{df}=1(P=0.17) ; \mathrm{I}^{2}=47 \% \\
\text { Test for overall effect: } Z=0.28(P=0.78)\end{array}$} & 0.01 & $\begin{array}{ccccc}1 & 1 & 1 & 10 & 100 \\
1 & 0.1 & 1 & \\
\text { Favours } & {[\mathrm{HM}]} & \text { Favours [No } \\
\text { HM] }\end{array}$ \\
\hline
\end{tabular}

Supplementary Figure 3 (A) Risk of GERD in patients with prior HM vs no prior HM (B) Risk of esophagitis in patients with prior HM vs no prior HM 